Ssciendo Studia Anglica Posnaniensia 55s2 (2020): 335-351

doi: 10.2478/stap-2020-0017

\title{
A FOLKLORISTIC ANALYSIS OF POLISH IMMIGRANT NARRATIVES IN WESTERN CANADA
}

\author{
JAMES I. DEUTSCH ${ }^{1}$
}

\begin{abstract}
The large wave of Polish immigration to Canada during the years immediately following World War II also brought the production of written narratives that reflect upon the process of migration and settlement in the new place. Although these migrants included persons from all across Poland, of different age groups, backgrounds, and occupations, the migration narratives share certain distinctive formulas and patterns, particularly in terms of their plot lines and narrative structure. Each story highlights the journey and its difficulties, the arrival and culture shock, the struggle to adapt, and finally acceptance of life in the new world. This article focuses on the migration experiences of Józef Bauer (arriving in Canada in 1946), Helena Beznowska (arriving 1948), Marian Pawiński (arriving 1949), and Erika Wolf-May (arriving 1953). Explored from a folkloristic perspective, these four narratives fulfill the four functions of folklore: entertainment, education, validation and reinforcement of beliefs and conduct, and maintaining the stability, solidarity, cohesiveness, and continuity of a group within the larger mass culture. Moreover, as folkloric expressions of culture, the narratives not only reflect our very human culture, but also reinforce our shared humanity.
\end{abstract}

Keywords: Canada; folklore; immigration/migration; life writing; Poland; World War II.

\section{Introduction}

One of the largest waves of Polish immigration to Canada came during the years immediately following World War II. Between 1946 and 1956, nearly 62,000 Poles arrived in Canada - many of whom did not wish to return to a Poland that the Communist Party had controlled since 1945 (Makowski 1987: 2). The migrants included many Displaced Persons who at war's end had been liberated from Nazi concentration or forced-labor camps, as well as political refugees from communist Poland. Many of these migrants moved to the three western provinces of Manitoba,

$1 \quad$ Center for Folklife and Cultural Heritage, Smithsonian Institution; deutschj@si.edu 
Saskatchewan, and Alberta, which is where roughly 60 percent of all Polish Canadians were living in 1941 (Kogler 1968: 51-62). According to the 2016 census, around one million Canadians claim full or partial Polish ancestry, and 191,775 Canadians speak Polish as a mother-tongue language (Heydenkorn 2019).

This article examines some of the memoirs and other first-person narratives from the Polish migrants who came to Canada between 1946 and 1956 and who helped to create a more multicultural nation. Although these migrants included persons from all across Poland, of different age groups, backgrounds, and occupations, their narratives share certain distinctive formulas and patterns, particularly in terms of the struggles, adaptations, and acceptances they experienced. I will analyze some of those formulas and elements from a folkloristic perspective, building upon some of the methods used by folklorists such as Linda Dégh, Giovanna Del Negro, and Amy Shuman, in their studies of personal narratives from immigrants and their descendants.

Although folklorists typically study personal narratives that come from fieldwork and/or oral-history interviews, and that are shared via oral communication, all of the memoirs and first-person narratives in this article come from printed sources, written by Polish migrants living in Canada. In some cases, the narratives were translated from Polish to English; in all cases, the narratives underwent an editing process before they were published. Nevertheless, they qualify as folkloric texts. Printed sources have long been reliable sources for folkloristics. As Barbara Kirshenblatt-Gimblett maintains, "Print is the pivot. ... New technologies [such as print] do not necessarily displace, replace, or eliminate earlier ones. They alter the relations among them and incorporate one anotherwith far-reaching effects" (Kirshenblatt-Gimblett 1998: 309-310). Moreover, as noted by the editor of one of the collections of narratives used here, these literary memoirs provide "a source for various kinds of scholarly research. These individual and personal testimonials often illuminate and explain various events, and always supplement the knowledge we have gleaned about some matter from other sources" (Heydenkorn 1979: i). Based upon Sandra K. D. Stahl's "The Personal Narrative as Folklore", these published narratives meet all the criteria for the folkloric, especially in the ways in which "there is more that is traditional than innovative" - as this article will demonstrate (Stahl 1977: 10).

Before examining the narratives themselves, some historical background on the immigration of Poles to Canada is necessary. The consensus is that the process can be divided into different waves of immigration - though the number of these waves varies according to different historians. For instance, Rudolf K. Kogler (born in Wadowice in 1919), who immigrated to Canada in 1952 and who worked as an economist and demographer with the Ontario Ministry of Treasury and Economy, sees three waves of immigration: the first wave from 1901 to 1910, when the population of Canada's Polish community increased 
fivefold from 6,300 to 33,700; the second wave from 1921 to 1931, following the First World War, when the Polish population in Canada grew roughly 10 percent each year; and the third wave from 1946 to 1961, following the Second World War, when "the size of the Polish community in Canada almost doubled... [and] grew consistently at a faster rate than the total Canadian population" (Kogler 1968: 52).

Similarly, Donald H. Avery and Jan Krzysztof Fedorowicz, historians at the University of Western Ontario, see three waves of Polish immigration, albeit with slightly different dates and numbers: the first wave from 1896 to 1914, when an estimated 110,000 Polish immigrants arrived in Canada - most of them from Galicia, who "were recruited by various steamship and railway companies... [and who] set out for government homesteads or railways lands scattered throughout the prairies" (1982: 6-10); the second wave from 1919 to 1939, following "the revival of the Polish state after 123 years of partition [which] was accompanied by colossal problems of reorganization and reconstruction", which brought immigrants seeking "high wages, guaranteed employment, and assisted passage through the auspices of the Canadian Pacific Railway Company and the newly formed Canadian National Railway system" (1982: 10-11); and the third wave coming after 1939, with migrants who "were to some extent motivated by economic considerations, but [whose] overriding impulse was a rejection of the communist system and a search for political liberty" (1982: 14). Unlike the previous two waves of immigrants, members of this third wave "had experienced severe physical and psychological traumas during the war and many had endured the uncertainties and regimentation of the European relief camps". As a result, "they found it difficult to adjust to the Canadian environment" (Avery \& Fedorowicz 1982: 14).

Still another historiographical interpretation of Polish immigrant to Canada comes from Benedykt Heydenkorn (born 1905 in Stara Bircza), a journalist and editor who immigrated to Canada in 1949 and who "is a recognized expert on the Polish Canadian community and Polonia, the Polish communities abroad" (Momryk 1993: iv). Heydenkorn (1999: 1849-1850) sees six waves of Polish immigration to Canada: the first wave from 1854 to 1901, especially from the Kashubia region of northern Poland to Ontario; the second wave from 1902 to 1915, just before immigration stopped during the First World War, when family groups received land grants from the government or bought lots to build farms in Manitoba, Saskatchewan, and Alberta; the third wave from 1916 to 1939, with Polish immigrants continuing to settle in the prairie provinces, making Manitoba "the largest Polish community in Canada" until 1944; the fourth wave from 1944 to 1956, consisting "largely of former soldiers of the Polish armed forces who had fought in Western Europe, former inmates of Nazi concentration or forcedlabour camps and political refugees from communist Poland" (1999: 1849); the fifth wave from 1957 to 1979 , which tended to settle in Ontario; and the sixth 
wave from 1981 to 1993 , which "was motivated by the deep economic and political crisis in Poland" (1999: 1849).

However the number of waves is counted, everyone seems to agree that the wave of immigration following World War II consisted of individuals who had been profoundly affected by the war. For instance, roughly 5,300 veterans of the Polish Army were admitted by Canadian authorities in 1946 and 1947 - the first half representing those who had served with the British Eighth Army in Italy, and the second half representing those who had served in England. The consensus is that "These immigrants represented an elite in Polish society and they possessed higher educational levels and more diverse skills than the earlier Polish immigrants. They were largely motivated by political concerns in deciding to emigrate to Canada. Having fought six years to secure an independent Poland, they preferred political exile to foreign domination in Poland" (Avery \& Fedorowicz 1982: 13). In addition to Army veterans, "Canada admitted some 166,000 displaced persons, approximately 39,000 of whom were Polish" between 1946 and 1952 (Avery \& Fedorowicz 1982: 13). Altogether, the number of Polish immigrants admitted into Canada between 1946 and 1956 totals 61,578 Polish citizens, which represents approximately 20 percent of all immigrants to Canada during the peak years of 1948 and 1949, according to one source (Makowski 1987: 2-3).

Although a relatively small percentage of these immigrants have shared their stories in print, the ones that could be identified - and that had been written in (or translated into) English display characteristics that lend themselves to a folkloric analysis. As a general rule, folklorists look for patterns and conventions, or what folklorists (and scholars of popular culture) call the formulaic. For instance, popular film and television rely on conventions and formulas - in terms of familiar plots and settings, such as for the western film, the detective film, the war film, the science fiction film, film noir, and others. Similarly, many folk narratives rely on familiar plots, settings, and even language - all of which enhance their adherence to tradition. Take, for instance, the beginning of many folktales: once upon a time, il était une fois, pewnego razu, es war ein mal, había una vez, c'era una volta, Жили были, and many more. Whatever the language, there is a formulaic opening - and a formulaic closing, often involving some variant of living happily ever after. Although many folklorists have explored the use of formula in ballads, folktales, and religious discourse, it seems equally applicable to personal narratives. As Gerald L. Davis's analysis of African American sermons indicates, "the appearance of a formulaic unit in the sermon may be directly related to the strength of the formula as a narrative event in a secular environment" (1985: 65). Similarly, the use of formulas and formulaic expressions in personal narratives enhances their strength through these familiar patterns and tropes. 
The folklore of migration covers what folklorist Linda Dégh (herself an immigrant to the United States from Hungary) calls a "broad field", including (in alphabetical order) arts, celebrations, costume, crafts, curses, evil-eye beliefs, magical medicine, nursery rhymes, proverbs, rituals, superstitions, weatherlore, witchcraft, and more (1996: 385). Much of this folklore deals with "the aesthetics of everyday life and the ways ordinary people artfully create meaning through daily interactions.... [A]lmost any kind of physical object or social activity that has been touched and transformed by the human spirit can be considered folklore" (Del Negro 2003: 13). The individuals whose narratives are analyzed here are certainly "ordinary people", whose memoirs "are undoubtedly the most valuable" when it comes to understanding social history (Heydenkorn 1979: i).

One of the most powerful ways in which ordinary people create meaning is through what Dégh terms "testimonies", in which immigrants (from Central and Eastern Europe, in Dégh's research) recall their arrival in the New World and how they "adapted themselves more or less gradually to the new environment" (1966: 552). Thanks in part to the formulaic quality of folklore, these testimonies frequently follow familiar patterns. In their study of trauma narratives related by refugees to the United States, folklorist Amy Shuman and lawyer/sociologist Carol Bohmer discovered that these "narratives are sometimes remarkably similar" (2004: 397). The stories not only "followed similar plotlines", but also "related a collective sense of grief about the loss". Moreover, the stories were sometimes so similar that they "could make listeners suspicious that one teller had copied another" (Shuman \& Bohmer 2004: 397).

Also striking is that these narratives - even though often mundane in their quotidian detail - reveal the rich expressive culture of the immigrant communities. For instance, Giovanna Del Negro's study of nine Italian women who immigrated to Montreal, demonstrates that "these women's lives clearly show how knowledge and meaning grow out of everyday experience as much as they arise from the ivory towers of academia" (2003: 11). Moreover, in ways that reinforce the findings of Shuman and Bohmer, Del Negro found that the "narratives about everyday events and the life story are part of a cultural repertoire that draws heavily upon familiar literary genre", including such familiar plot lines as "the hero's quest, the immigration saga, the family tragedy and the survival tale" (2003: 22). According to Del Negro, "our desire to narrativize human experience and dramatize the past stems from an effort to reorganize events in meaningful terms" (2003: 23).

The remainder of this article will analyze four such narratives that not only reorganize events in meaningful terms, but that also readily lend themselves to the type of formulaic analysis conducted by folklorists. The plot lines that emerge from these narratives divide themselves into four episodes that make up the immigrant's journey to Canada and that form a corpus of tradition: 
1. The Journey and Its Difficulties

2. Arrival and Culture Shock

3. Struggling to Adapt

4. Acceptance of Life in the New World

Each of these elements will be analyzed in the following four narratives. The narratives are treated chronologically, according to each immigrant's date of arrival in Canada, in order to maintain historical consistency and sequence.

\section{Four formulaic narratives of immigration}

Józef Bauer was born in Rożnów (not far from Kraków) in 1925, and arrived by ship at the port of Halifax, Nova Scotia, on 13 November 1946, from which he traveled further west. His personal narrative of immigration, titled "Najmłodszy Żołnierz" ("The Youngest Soldier"), was one of five memoirs published in the first volume of Pamiętniki imigrantów polskich w Kanadzie (1975), edited by Benedykt Heydenkorn. This volume - as well as the two that followed in 1977 and 1979 - were the result of a widely advertised competition organized by the Canadian Polish Research Institute in December 1971 to find memoirs of Polish immigrants to Canada. According to the original call for memoirs, literary quality was not a criterion for judging in the competition: "What is important is the memoir's authenticity" (Heydenkorn 1979: iii). Altogether twenty-three memoirs were published in the three volumes, eleven of which (including Bauer's) were translated into English and published in 1979 as Memoirs of Polish Immigrants in Canada, also edited by Heydenkorn.

Bauer's means of immigrating to Canada was especially complicated - not a simple matter of traveling from Poland to Canada. Following the successive invasions of Poland in September 1939, first by the Nazis and then by the Soviets, Bauer flees the country and ends up in Romania, Turkey, Palestine, Egypt, Lebanon, Iraq, and Italy - sometimes in prison, sometimes in uniform, and sometimes on the run. Wounded in combat at Monte Cassino, Bauer recuperates in a hospital and serves until the war's end as an orderly to a major. Not wishing to return to a Communist-controlled Poland, Bauer opts instead for Canada, which has agreed to accept 4,000 Polish veterans as farm laborers. Shortly after arriving in Halifax in 1946, Bauer keeps moving, and finds a wide variety of jobs in different places across the country: in Brand, Manitoba; in Kipling, Saskatchewan; back in Toronto; in Newmarket, Ontario; back in Toronto; in Gravenhurst, Ontario; and finally back in Toronto. He also was married twice (Bauer 1979: 1-40).

In spite of his complicated peregrinations throughout Central Europe, Eastern Europe, the Middle East, and Canada, Bauer's narrative fits the four-part episodic plot. Elements of "The Journey and Its Difficulties" are ever-present throughout 
Bauer's story as he makes his way from Europe:

- $\quad$ "So, taking advantage of this offer [to work as a farm laborer], I signed up for Canada. But as it turned out. It wasn't quite as easy as it seemed" (Bauer 1979: 4).

- $\quad$ "By the time that night rolled around, we were already off on our long road ahead. In the train, they read us our assignments - that is to say, they told us which province we would be going to. I happened to get the province of Ontario and so the trip proved to be long and tiresome" (Bauer 1979: 5).

- $\quad$ "To my surprise they kept me in the hospital as a patient, along with about a hundred others who had come on the same train to me [to Ontario]. They wouldn't tell us why but I overheard a conversation between two orderlies, who said that we were suspected of having tuberculosis" (Bauer 1979: 5).

Likewise, elements of "Arrival and Culture Shock" frequently appear throughout Bauer's narrative, especially due to the working conditions he finds in Canada:

- "And so, I broke my back from morning till night. While they [the Canadian farmers] ate their food, I ate mine, which was always served to me in the corner as if I was an orphan" (Bauer 1979: 11).

- $\quad$ "All of this hit me like a bomb [when threatened with deportation]. I was so shaken and angry that if I'd had a Tommy Gun with me, I'd have blown them all to kingdom come, and me along with them, right then and there" (Bauer 1979: 21).

- $\quad$ "This was just too much for me to stand [when threatened with arrest]. I said this to him, or rather hollered 'Listen, I came to Canada legally. If I got sick then it's your own bloody fault, not mine. I had to work like a horse on those farms, you know. Look, pal, I understand why you had to come here. I know it's your job. But that doesn't give you the right to yell at me or to treat me the way you are doing. I'm no criminal. So would you please get out of the house right now, and be quick about it, if you don't want to go head first down those stairs!"' (Bauer 1979: 30).

Throughout Bauer's narrative, examples of "Struggling to Adapt" appear on nearly every page:

- $\quad$ "I came back to Toronto, and we decided that my wife would get a job while I'd go to a barber's school and learn a trade. The fact was that it was getting more and more difficult to find a job then.... After I got my diploma, I loaded all my things on a small truck and, like a gypsy, started 
travelling all over Ontario looking for a place where I might make a few dollars as a barber. The thing was, though that I wanted to find a place where there wouldn't be too much competition. I tried almost every spot in northern Ontario, but found that there were a lot of barbershops everywhere" (Bauer 1979: 36).

- $\quad$ "[T] me Canada is just like the Foreign Legion. Everybody looks out for himself, and there are so many national minority groups who can't get along with each other. To put it simply, there's no unity" (Bauer 1979: 38).

Finally, after experiencing so many difficulties and so much struggle throughout his life, Bauer finds a steady, good-paying job, and is able to accept a comfortable life with his wife in Toronto:

- "All in all, it's not too bad. With a little overtime added, I can make up to $\$ 190$ a week. Of course, I don't get to keep it all because they take off for taxes and other deduction, but I still manage to have some left over for myself. I've bought a little three-room house, which I've done up nicely, and I'm living with my wife like a king" (Bauer 1979: 40).

One might imagine that Józef Bauer's peregrinations could not be matched. However, the story of Helena Beznowska - written by her daughter, Apolonja Maria Kojder, as “A Mother's Legacy” in Marynia, Don't Cry: Memoirs of Two Polish-Canadian Families - is nearly as complicated, and includes the same primary plot lines. Beznowska was born on 27 September 1919 in the Sokal District, near what is now Lviv, Ukraine. During the chaos of World War II, she was forced out of Poland - first to a Soviet labor camp in Siberia, then across Central Asia to a collective farm in Uzbekistan, followed by refugee camps in Iran and India, and through the Suez Canal to England. She left Southampton by ship on 7 July 1948, and arrived in Quebec, Canada, on 17 July 1948. Like other Polish Displaced Persons, she traveled west: via Winnipeg to Speers, Saskatchewan.

Even without describing the travails in Siberia, Uzbekistan, Persia, and Iran, Kojder's narrative has much to say about her "journey and its difficulties". For example:

- $\quad$ "September 23 [1947] found the passengers on a turbulent Atlantic Ocean. Many of the passengers were seasick. Again the climate had changed and there was need for a sweater, coat, and socks" (Kojder \& Głogowska 1995: 101).

- $\quad$ "That day [at a refugee camp in England] Helena had to stand in line for five hours to register. She was exhausted, her feet hurt, and her temperature was above normal" (Kojder \& Głogowska 1995: 101). 
- $\quad$ "They boarded the Kota Inten-Line 7 [to Canada]. It was July 7, 1948. There were very few Poles on the ship, but there were many large Dutch families going to Ontario who wanted to buy fruit farms. The food was bad, and the cabins crowded. It was a small ship, which seemed to crawl at a snail's pace, but finally, ten days later, they arrived in Canada" (Kojder \& Głogowska 1995: 103-104).

Throughout her journeys, Beznowska experiences multiple moments of shock - both upon her arrivals in England and Canada:

- $\quad$ "Helena's first impressions of England were bad. After India, it was strange to see white people working so hard; she was living in a barrel; the food was terrible; it was cold and she was hungry. It was like Russia and Czary [site of the Soviet labor camp in Siberia] all over again" (Kojder \& Głogowska 1995: 102).

- $\quad$ "The first view of this new country was pleasant, but after their train had passed through Quebec and Ontario and was well on its way out west, all that Helena could see was parched yellow prairie grass. There were no people anywhere. She started to cry. Why was she coming to this wilderness? She couldn't help but remember how beautiful the English countryside was that spring and summer" (Kojder \& Głogowska 1995: 104).

- $\quad$ "All she could see were bushes and farm houses here and there in the fields, scattered far apart. And every few kilometres stood the tall distinctive grain elevators next to the railway tracks, announcing another village. Russia had looked better than this. In the three days it had taken to come from Quebec to Saskatchewan, Helena had become completely disenchanted" (Kojder \& Głogowska 1995: 104).

Even with the support of her husband and father in Saskatchewan, Beznowska struggles to adapt and adjust to her new environment, especially after giving birth to her first child, and later taking a job as a nurse:

- $\quad$ "In those days nobody cared about immigrants or gave them anything, although Helena started receiving the family allowance or baby bonus when the baby was born. Helena's hospital stay cost $\$ 120$, at a time when nurses were earning $\$ 80$ a month" (Kojder \& Głogowska 1995: 106).

- $\quad$ "On the farm there were no luxuries, but the farmers of the district, mostly English, Scottish, American, German, and a few Swedes, tried to make the Kojders feel at home... Helena appreciated their kindness and tried to make the best of the situation, even though someone had to go about a mile to fetch water from the well for cooking and washing diapers" (Kojder \& Głogowska 1995: 106). 
- $\quad$ "Helena found nursing in Canada more difficult than overseas. The wages were low, and she only had one day off a week. And, in Canada, the nurses had to do much more menial work. Also, even though she had a broad range of experiences and training, she felt she had to prove herself because as an outsider, that the staff watched her more closely. She felt isolated and ill at ease because her life experiences were so different from those of her Canadian colleagues. Often she would come home crying. But she survived by always being busy so that no one could bother her" (Kojder \& Głogowska 1995: 110).

More difficulties struck Beznowska and her family in Saskatchewan; her husband was killed in a work accident; her mother died five years later at age seventy-six; and Beznowska suffers a pulmonary embolism in her right lung, forcing her to stop work for one year. Even though told she will never work again, she is able not only to accept life in the new world, but to thrive. With an exercise regimen, she is able to return to work within a year and continue working until her retirement ten years later. The title of the volume - and the words she heard her grandmother tell her mother - are what provide her with the will to continue: "Marynia, don't cry. As long as I'm alive I will help you. And maybe you will survive longer because nobody will bother you. And later your children will help you" (Kojder \& Głogowska 1995: 18). Beznowska's acceptance of life in the new world is neatly summarized in a passage near the end of the memoir:

- "She has come a long way from that young immigrant woman who used to come home crying. Thirty-five years and seven months. Since retiring, Helena nursed part time for a while and now looks after the small family real estate business; she also has learned how to swim, has become an avid reader, and enjoys a wide circle of friends, all things she never had time for while working" (Kojder \& Głogowska 1995: 112).

The third narrative comes from Marian Pawiński, who was born in 1919 in Poland, but deported to Germany in January 1940 at age twenty-one for forced labor. Following the war, like thousands of other Poles, Pawiński decided not to return to Poland and instead to immigrate to the new world. His journeys were not nearly as complicated as Bauer's or Beznowska's, but like Bauer his memoir was selected for publication in Pamiętniki imigrantów polskich w Kanadzie under the title "W roli emigranta" ("My Life as an Immigrant") in volume two (1977), and subsequently translated into English and published in Memoirs of Polish Immigrants in Canada (1979).

Even if relatively uncomplicated, Pawiński's journeys were never easy, but rather filled with difficulties, especially a longing for what is being lost: 
- $\quad$ "The day of departure came. It was a decisive day for me and it stayed in my mind for a long time. We stood on the deck of the ship, with a feeling of happiness mixed with melancholy" (Pawinski 1979: 147).

- "Only a moment remained before our final separation with Europe. Suddenly the protracted hooting of the ship's siren filled the air. It echoed deeply in my heart, like an instrument playing a false note" (Pawinski 1979: 147).

- $\quad$ "The farther we sailed from the continent, the closer Europe seemed to me. We only value what is dearest and closest to us when we lose it. My journey was an emotional one, filled with strong impressions that affected my receptive mind" (Pawinski 1979: 147).

When Pawiński first arrives in Canada in 1949, he is amazed by the vast natural landscapes and the availability of resources and work, seeing it as "an impressive expanse of land like ocean or the world of abstraction where the spirit soars unhampered into an unexplored and boundless space" (Pawinski 1979: 47). However, as time passes, his positive impressions of Canada begin to rapidly decline, and are replaced by episodes of culture shock:

- $\quad$ "Canada is an artificial creation where everyone takes, and nobody gives anything back in return.... this vast territory that is rich in mineral wealth but whose society, despite its appearance, does not have a national identity of its own" (Pawinski 1979: 151).

- $\quad$ "In my opinion, Canada, with its high level of civilization, its prosperity and its technological advancements, is nevertheless still the wild and morally corrupt West, governed by the principle of physical laws" (Pawinski 1979: 153).

Taking a job as a miner, Pawiński finds challenges in the non-European mindset of rural Canada, and struggles to adapt to the differences he finds in family life, schooling, and work.

- $\quad$ "As time passes (a great disadvantage for us), we find that our child is growing away from us. The influence, the advice, and the discipline at home that were accepted passively until now begin to cause resistance" (Pawinski 1979: 152).

- $\quad$ "Could I have changed my mental and spiritual make-up and become a realist? That is a physical impossibility. It is as if a fly had landed on the paper while I was writing and I kept trying to chase it away and this maneuver was repeated again and again.... The fact that I am aware of this serves little or no purpose" (Pawinski 1979: 154). 
After struggling to find himself within Canada and its culture, Pawiński moved in 1958 to the Soviet Union, where he lived for two years. Upon his return to Canada, he is no longer struggling to adapt, but finally is able to accept his life in his new home.

- $\quad$ "Although Canada was not my kind of world, I missed the country and its freedom for the individual. I only came to value and understand this freedom more deeply when I temporarily lost it" (Pawinski 1979: 164).

- "Although I knew I would continue to be a malcontent, my attitude towards Canada underwent a fundamental change... Canada's greatest wealth lies in the freedom that it offers the individual. For this reason I am completely loyal to Canada and I would fight and lay down my life for this country if I ever had to do so" (Pawinski 1979: 164).

The last of the four narratives examined here is by Erika Wolf-May, born in Poland in 1922, the daughter of Karol Wolf (born in Jarosław) and Wanda Kosiba (born in Bochnia). Following Germany's invasion of Poland on 1 September 1939, she and members of her family "fled for their lives" and were "caught in the crossfire between the Germans and the Russians" (Wolf-May 2002: 82). At war's end, having been declared a Displaced Person from Germany, Wolf-May was able to immigrate to Canada. She arrived in Halifax, Nova Scotia on 1 January 1953, took a train to Montreal, and then moved west to Moose Jaw, Saskatchewan. Like the previous three immigrant journeys, Wolf-May's was filled with difficulties.

- $\quad$ "Coming to Canada aboard the [ship] Beaverbrae proved to be anything but smooth sailing. We left Germany at a very bad time of the year: December. The ocean's murky waters were crowned with icebergs, for one, and at times we were caught between the angry jaws of the water. Waves covered the deck of the ship relentlessly; and when that happened, we were confined to our bunks below the ship's stern. Here we were tossed like rag dolls. Many of us fell ill and all of us prayed that we would arrive safely to the port of Halifax" (Wolf-May 2002: 64).

- $\quad$ "Eating was another art one had to master while aboard the Beaverbrae. If you were lucky enough, you might be able to maneuver one mouthful of food into your mouth before your plate slide to the opposite end of the table. One would literally have to get up and anchor their plate" (WolfMay 2002: 64-65).

As immigrants like Wolf-May began arriving in Canada in increasingly large numbers, many of them were individuals and members of families who had never 
left Poland, much less their hometown or village. Wolf-May for one was shocked - albeit pleasantly so - by what she encountered:

- $\quad$ "My first impressions of Canada were no less than perfect. Not a cloud marred the blue sky, which was indeed a good omen I concluded. That first day in Canada, I was certain that no other place in the world could be more beautiful" (Wolf-May 2002: 66).

- "Food was very expensive in Germany in 1953, ever since the war began. Therefore, we had very little and certainly no extras. Here in Canada, the food seemed to be plentiful. Wonderful, wonderful food! Food I had never been introduced to in my entire life! We had ham, eggs, butter, fruits, and peanut butter" (Wolf-May 2002: 68).

- $\quad$ Peanut butter... I was ecstatic! My delight at having my own peanut butter was a dream come true. Peanut butter was not a food that could be purchased by just anyone in Germany. It was very expensive and was considered a 'luxury food"' (Wolf-May 2002: 68-69).

Wolf-May's delight at her new surroundings in Saskatchewan quickly dissipated, as she faced the challenges of starting a new life and struggling to adapt:

- $\quad$ "It soon became apparent, however, that one wage could not sustain our household and pay all of our bills: clothing, food, rent, power, heat, phone, and transportation. I would have to find myself a job and soon" (Wolf-May 2002: 70).

- $\quad$ "For eleven months, I worked the evening shift at the hospital. My coworkers enjoyed laughing at my poor English behind my back, but my pride did not allow me to sink to their level. I was defiant in my thinking when facing the enemy" (Wolf-May 2002: 70).

After living in Canada for many years, struggling to make ends meet and prove herself to her coworkers, Wolf-May finds work as a medical photographer and worked "with great fervency" until her retirement in 1987 at the age of sixty-five (2002: 78). Even after losing both legs due to a life-threatening disease, she succeeded in learning how to walk on prosthetics and found complete acceptance of her life in the new world:

- $\quad$ "Today I live the quiet life. I play the organ, listen to music, read, do puzzles, watch a little television, visit friends and family. On other occasions it is reversed and friends and family visit me. Other times I sit at the table with a sherry in my hand while enjoying the view beyond my window: the river with its boats and the people caressing its highway and just life in general" (Wolf-May 2002: 80). 


\section{Conclusion}

Certainly there exist other memoirs of Polish immigrants to Canada during the post-World War II period. Perhaps not all of them will contain what this folkloristic analysis has identified as the four primary plot lines: the journey and its difficulties, arrival and culture shock, struggling to adapt, and acceptance of life in the new world. However, what seems especially striking is the consistency and continuity of these plot lines among four very different individuals. Sandra K. D. Stahl's investigation into "The Personal Narrative as Folklore" may help to explain some of these consistencies. She observes that the plot of any personal narrative is "nontraditional almost by definition" because "it is based on an experience that is seemingly personal and developed in a story that is seemingly idiosyncratic" (1977: 14). Certainly, the migration experiences of Józef Bauer, Helena Beznowska, Marian Pawiński, and Erika Wolf-May are both personal and idiosyncratic - given their vastly different circumstances and life trajectories: Bauer as a sometimes-prisoner and sometimes-soldier in uniform through Europe and the Middle East; Beznowska as refugee in Siberia, Uzbekistan, Persia, and Iran; Pawiński as a forced laborer in Germany; and Wolf-May as a person displaced by the war. However, the structural similarities of their stories reinforce what Stahl regards as the folkloric character of the personal narrative. Although the "experience related in a personal narrative is not exactly like the plot of any traditional story", it adheres to tradition more than to innovation, and to continuity more than change (Stahl 1977: 15).

Moreover, the formulaic quality of these narratives should in no way raise any suspicions about their veracity or authenticity. Folkloric does not mean fictional. To the contrary, the patterns and formulas seem to reinforce their validity as authentic expression. The delivery of an African American sermon - with all of its formulaic qualities - "is an expression of power, of control over the events of one's life, and has the power to reinvent and relive portions of an earlier experience that may yet have significance in the life of the group or individual" (Davis 1985: 100). Admittedly, reading these narratives is a different experience than hearing a sermon, but one can nevertheless feel the authenticity of the individual through the printed page.

Folklorists have found that all expressions of folk culture may simultaneously serve several functions. In his seminal article, William R. Bascom identified four functions, admitting that they "could be classified differently" (1954: 348). That being said, one function is surely entertainment, which we find in the sharing and enjoyment of these stories. Artful storytellers, such as Bauer, Beznowska, Pawiński, and Wolf-May use language that amuses and entertains at the same time as it informs. For instance, when Bauer writes about eating his food in the corner of a Saskatchewan farmhouse, as if he "was an orphan", we as readers find 
pleasure in his vivid descriptions of the situation (1979: 11). Similarly, we feel and appreciate Wolf-May's ecstasy at eating unlimited amounts of peanut butter in her new Saskatchewan home.

A second function is education, which we find in the information conveyed by the storytellers. Given that stories about Polish immigrants to Canada are very likely to be heard or read by other Polish immigrants to Canada, or even by nonPoles or non-immigrants, it seems clear that people are being educated - in a traditional form that takes place outside formal educational institutions - about a wide variety of beliefs, values, customs, and ideas. From these four memoirs we learn about strategies for survival amidst hardship, and perhaps also how to accept what life has dealt them.

A third function is validation and reinforcement of beliefs and conduct. The formulaic repetition of the immigrant journey and struggle to adapt helps to reinforce our knowledge and expectations of the immigration experience itself. Realizing that your own experience is not unique, but rather is something that is shared by others within your ethnic, occupational, racial, regional, or religious groups, helps to validate the experience itself, and to understand that it may be part of longstanding, continuous traditions.

The three previous functions add up to the most important function of maintaining the stability, solidarity, cohesiveness, and continuity of a group within the larger mass culture. All folk groups - whether ethnic, occupational, racial, regional, or religious - are interested in preserving their own group identity; and the maintenance and sharing of folklore is one very effective way to do so. The cultural beliefs expressed in folklore grow out of a shared cluster of hopes, frustrations, fears, and joys that are experienced in common by a substantial number of the group's membership.

The importance of narratives cannot be underestimated in the maintenance of a group's stability, solidarity, cohesiveness, and continuity. Ryszard Dubanski (born in 1947), for instance, was too young to recall the journey that he and his Polish parents made to Winnipeg's North End from a Displaced Persons camp near England's Sherwood Forest. But growing up in Canada, he heard his mother tell "war stories" repeatedly, as if "in a seemingly endless loop" (2005: 46). Nevertheless, the significance of these stories in maintaining the group's culture was also clear to Dubanski, even as a young boy. "These narratives of survival were important at home, the essence of our family history" (2005: 46).

As we have seen, the stories of Polish immigration to Canada are primarily stories of survival, adaptation, and acceptance. As such, they may become what psychologists Alice Hoffman and Howard Hoffman termed "a subset of autobiographical long-term memory which is so permanent and largely immutable that it is best described as archival", in the sense that they "are rehearsed, readily available for recall, and selected for preservation over the lifetime of the individual. 
They are memories selected much as one makes a scrapbook of photographs, pasting in some, discarding others; they define the self and constitute the persona one retains, the sense of identity over time" (1990: 145).

Human beings, of course, are neither scrapbooks nor archives. The personal narratives that we generate, and the ways in which we tell them - changing over time, or not changing over time - are folkloric expressions of culture. We may never forget something as long as we live (as the saying goes), which further underscores how these narratives not only reflect our very human culture, but also reinforce our shared humanity.

Acknowledgements

Research assistance for this article was provided by several interns at the Smithsonian Center for Folklife and Cultural Heritage, including Justin Devine, Samuel Jane-Akson, and Michael Sheridan.

\section{REFERENCES}

Avery, Donald H. \& Jan K. Fedorowicz. 1982. The Poles in Canada. Canadian Historical Association.

Bascom, William R. 1954. Four functions of folklore. Journal of American Folklore 67(266). 333 349. DOI: $10.2307 / 536411$

Bauer, Józef. 1979. The youngest soldier. In Benedykt Heydenkorn (ed.), Memoirs of Polish immigrants in Canada. Toronto: Canadian-Polish Research Institute. 1-40. Based on the original Polish three-volume edition, Pamiętniki imigrantów polskich $w$ Kanadzie. 1975-1978. Polish Alliance Press.

Davis, Gerald L. 1985. I got the word in me and I can sing it, you know: A study of the pPerformed African-American sermon. University of Pennsylvania Press. DOI: $10.9783 / 9781512801637$

Dégh, Linda. 1966. Approaches to folklore research among immigrant groups. Journal of American Folklore 79(314). 551-556. DOI: 10.2307/538220

Dégh, Linda. 1996. Study of immigrant folklore. In Jan Harold Brunvand (ed.), American folklore: An encyclopedia. Garland Publishing. 385-388.

Del Negro, Giovanna. 2003 Looking through my mother's eyes: Life stories of nine Italian immigrant women in Canada. (2nd edn.) Guernica Editions.

Dubanski, Ryszard. 2005. Black teeth \& other North End souvenirs. Signature Editions.

Heydenkorn, Benedykt. 1979. Introduction. In Benedykt Heydenkorn (ed.), Memoirs of Polish immigrants in Canada. Toronto: Canadian-Polish Research Institute. i-x. Based on the original Polish three-volume edition, Pamiętniki imigrantów polskich w Kanadzie. 1975-1978. Polish Alliance Press.

Heydenkorn, Benedykt. 1999. Poles. In James H. Marsh (ed.), The Canadian Encyclopedia. McClelland \& Stewart. 1849-1850. 


\section{A folkloristic analysis of Polish immigrant narratives in Western Canada 351}

Heydenkorn, Benedykt. 2019. Polish Canadians. The Canadian Encyclopedia (accessed 31/07/2020). https://www.thecanadianencyclopedia.ca/en/article/poles

Hoffman, Alice M. \& Howard S. Hoffman. 1990. Archives of memory: A soldier recalls World War II. University Press of Kentucky.

Kirshenblatt-Gimblett, Barbara. 1998. Folklore's crisis. Journal of American Folklore 111(441). 281-327. DOI: $10.2307 / 541312$

Kogler, Rudolf K. 1968. Demographic profile of the Polish community in Canada. Polish American Studies 25(1). 51-62.

Kojder, Apolonja Maria \& Barbara Głogowska. 1995. Marynia, don't cry: Memoirs of two PolishCanadian families. Multicultural History Society of Ontario.

Kozak, Jacek. 2011. How the Polish created Canada. Dragon Hill Publishing.

Makowski, William. 1987. The Polish people in Canada: A visual history. Tundra Books.

Momryk, Myron. 1993. Benedykt Heydenkorn: Finding Aid No. 1947. Library and Archives Canada, Manuscript Division, Multicultural Archives Program. https://docplayer.net/57223427-Mg-31-d-237-heydenkorn-benedykt-finding-aid-noinstrument-de-recherche-no-1947.html

Pawinski, Marian. 1979. My life as an immigrant. In Benedykt Heydenkorn (ed.), Memoirs of Polish immigrants in Canada. Toronto: Canadian-Polish Research Institute. 145-174. Based on the original Polish three-volume edition, Pamiętniki imigrantów polskich $w$ Kanadzie. 1975-1978. Polish Alliance Press.

Shuman, Amy \& Carol Bohmer. 2004. Representing trauma: Political asylum narrative. Journal of American Folklore 117(466). 394-414. DOI: 10.1353/jaf.2004.0100

Stahl, Sandra K. D. 1977. The personal narrative as folklore. Journal of the Folklore Institute 14(12). 9-30. DOI: $10.2307 / 3814039$

Wolf-May, Erika. 2002. Erika: The story of my life. Lighthouse Publishers. 